Babeş-Bolyai

University

Cluj-Napoca

\title{
TRANSYLVANIAN REVIEW
}

\section{OF ADMINISTRATIVE SCIENCES}




\title{
Babeş-Bolyai University \\ Faculty of Political, Administrative and Communication Sciences \\ Department of Public Administration and Management \\ Transylvanian Review of Administrative Sciences
}

\author{
Special Issue / December / 2017
}

Communities and local sustainable development

\author{
Guest Editors:
}

Cristina HARUŢA \& Octavian MOLDOVAN 
Senior Editor: Călin Emilian Hinţea

Director: Ciprian Tripon

Editor: Cristina Mora

Administrative director: Ovidiu Boldor

Editorial Board: Balogh Marton, Daniel Buda, Marius Dodu, Dacian Dragoş, Călin Ghiolţan, Veronica Junjan, Dan Lazăr, Elena Minea, Natalia Negrea, Liviu Radu, Sorin Dan Şandor, Bogdana Neamţu, Bianca Radu, Raluca Gârboan, Adrian Hudrea, Cornelia Macarie, Dan Balica, Tudor Ţiclău, Cristina Haruţa, Horia Raboca, Raluca Suciu, Ana Elena Ranta, Octavian Moldovan

\section{INTERNATIONAL ADVISORY BOARD}

Carole NEVES, Smithsonian Institute, Washington, DC

Allan ROSENBAUM, Florida International University

Arno LOESSNER, University of Delaware

Roger HAMLIN, Michigan State University

Laszlo VARADI, Corvinus University of Budapest

Eric STRAUSS, Michigan State University

Gyorgy JENEI, Corvinus University of Budapest

Adriano GIOVANNELLI, Genoa University

Bernadine Van GRAMBERG, Victoria University

Julian TEICHER, Monash University

Geert BOUCKAERT, Catholic University of Leuven

Veronica JUNJAN, University of Twente

György HAJNAL, Corvinus University of Budapest

Taco BRANDSEN, Radboud University Nijmegen, Secretary-General

of the European Association for Public Administration Accreditation (EAPAA)

Juraj NEMEC, Masaryk University, president of The Network of Institutes and Schools

of Public Administration in Central and Eastern Europe (Nispacee)

Maria ARISTIGUETA, University of Delaware

Yüksel DEMIRKAYA, Marmara University

Marian PREDA, University of Bucharest

Marius PROFIROIU, Bucharest Academy of Economic Studies

Alexander HENDERSON, Long Island University

Gregory PORUMBESCU, Northern Illinois University

Transylvanian Review of Administrative Sciences has been selected for coverage in Thomson Reuters products and custom information services. Beginning with no. 22E/2008, this publication is indexed and abstracted in the following:

1. Social Sciences Citation index ${ }^{\circledR}$

2. Social Scisearch ${ }^{\circledR}$

3. Journal Citation Report/Social Sciences Edition

Transylvanian Review of Administrative Sciences is also listed in EBSCO, IBSS - International Bibliography of Social Sciences, Elsevier Bibliographic Databases, PA@BABEL Public Administration's dataBase for Accessing academic publications in European Languages and DOAJ - Directory of open access journals. 


\section{CONTENTS}

Raffaella AVERSA

Relly Victoria V. PETRESCU

Antonio APICELLA

Florian Ion T. PETRESCU

5 Modern Transportation and Photovoltaic Energy for Urban Ecotourism

Aslı BOZDAĞ

Münevver Gizem GÜMÜŞ

Kutalmış GÜMÜŞ

Savaş DURDURAN

21 Accessibility Analysis for the Elderly in an Urban Area from Turkey

Adina CANDREA

Cristinel CONSTANTIN

Ana ISPAS

38 Public-Private Partnerships for a Sustainable Tourism Development of Urban Destinations. The Case of Braşov, Romania

Laura Maria IRIMIEȘ

57 Lobbying and Social Participation - Key Features

for an Effective Public Administration in Romania

Daniela Angelina JELINČIĆ

Sanja TIŠMA

Matea SENKIĆ

Domagoj DODIG

74 Public-Private Partnership in Cultural Heritage Sector

Alicja K. ZAWADZKA

90 Making Small Towns Visible in Europe: the Case of Cittaslow Network

- The Strategy Based on Sustainable Development 


\section{PUBLIC-PRIVATE PARTNERSHIP IN CULTURAL HERITAGE SECTOR}

\section{Daniela Angelina JELINČIĆ Sanja TIŠMA Matea SENKIĆ Domagoj DODIG}

\author{
Daniela Angelina JELINČIĆ (Corresponding author) \\ $\mathrm{PhD}$, Researcher \\ Department for Culture and Communication, Institute for \\ Development and International Relations, Zagreb, Croatia \\ Tel.: 00385-14-877.487 \\ E-mail: daniela@irmo.hr
}

\section{Sanja TIŠMA}

\section{$\mathrm{PhD}$, Researcher}

Department for Resource Economics, Environmental

Protection and Regional Development, Institute for

Development and International Relations, Zagreb, Croatia

\section{Matea SENKIC}

MA, Associate

Department for Culture and Communication, Institute for

Development and International Relations, Zagreb, Croatia

\section{Domagoj DODIG}

Adviser

Agency for Investments and Competitiveness, Zagreb, Croatia

\section{Abstract}

Over the past few decades public-private partnership or PPP has become a new way for delivering and financing public sector projects. It may involve investment in fully economic infrastructure such as highways, railways, airports, seaports, etc. up to the investments in social infrastructure projects, such as schools, hospitals, museums and other significant and historic buildings of public interest.

The main objective of this article is to analyze the situation in Croatia, Poland, Slovakia and Slovenia concerning the topic of public-private partnership (PPP) in order to provide grounds for possible future investments in cultural heritage in these countries. For this purpose, a comparative analysis of legal and institutional frameworks was carried out as well as structured interviews with key stakeholders (public and private sector representatives). Special attention has been paid to the use of PPP projects in the revitalization of cultural heritage. The results of the analysis showed the lack of PPP investments in the cultural sector, and also identified possible obstacles in public sector administrative procedures.

The results of the analysis may be further used to stimulate both public authorities to set strategic directions for heritage revitalization plans based on PPP schemes as well as private investors who may seek feasible business models complemented with social responsibility benefits.

Keywords: public-private partnership, cultural heritage, Croatia, Poland, Slovakia, Slovenia. 


\section{Introduction}

The lack of financial resources in the field of culture encouraged the search for alternative financing models which resulted in a number of relatively recent scientific articles and studies (such as European Parliament, 2011; Ventura, Cassalia and Della Spina, 2016; Oppio and Torrieri, 2016; European Commission, 2016).

Financing models for culture range from the old fashion ones such as public support to those which so far have not been common in the field of culture (debt and equity finance, crowdfunding, risk mitigation schemes, etc.). Private financing has historically been present in the field of culture (such as the patronage system ${ }^{1}$ ), but has only lately been paid greater attention. Philanthropic, sponsorship and donation models have rather widely been common in the cultural sector for some time. Lately, greater focus has been put on various public-private initiatives including fiscal incentives (such as various tax relieves, percentage legislation, transfer of art in lieu of tax payment, earmarked taxes, vouchers), matching funds and the involvement of private companies in the management of cultural institutions. Built cultural heritage usually requires substantial investments due to construction works often needed for their revitalization. In this sector, public-private partnerships schemes have often been encouraged ranging from individual and entrepreneurial investments, joint ventures to grant-giving foundations which are usually with banking origins.

Cultural heritage for most of the governments remains one of the main burning issues not only because of the high costs of its renovation but also due to investments required for its protection and maintenance, especially in the Central Europe region. The aim of this article is to analyze the situation in Croatia, Poland, Slovakia and Slovenia concerning the topic of public-private partnership (PPP) in order to provide grounds for possible future investments in cultural heritage in these countries. Theoretical framework on public-private partnership is first presented explaining its benefits and differences from other delivery or procurement models. Then, the article focuses on PPP in the cultural sector in order to provide reliant examples of this scheme for culture. Current status of PPP in Croatia, Poland, Slovakia and Slovenia is presented providing a contextual analysis. The empirical part of the article focuses on the results of interviews conducted both with private and public sector representatives in order to detect possible obstacles and bottlenecks for greater promotion and implementation of PPP schemes. Interviews have been conducted within the RESTAURA project financed through the Interreg CE program of the European Union². Conclu-

1 Dating back to Gaius Maecenas Cilnio (68 BC - 8 AD), an influential adviser to the Roman Emperor Augustus, who established a circle of intellectuals and poets (e.g., Horace, Virgil and Propertius) that he personally protected, encouraged and supported in their artistic production.

2 The project is currently under way, having the duration from June 2016 throughout May 2019. Its aim is to identify, test, evaluate and promote good practice on PPP in revitalization of historic cities and buildings. 
sions are presented and complemented with recommendations which could enhance cultural heritage revitalization based on PPP.

\section{Theoretical background}

Generally, there is a low level of understanding of the public-private partnership term. A number of definitions exist and none is widely accepted despite the substantial knowledge collected on the topic, existing national regulations and international guidelines ${ }^{3}$. The PPP Knowledge Lab defines a PPP as 'a long-term contract between a private party and a government entity, for providing a public asset or service, in which the private party bears significant risk and management responsibility, and remuneration is linked to performance' (PPP Knowledge Lab, 2015). Similarly defined, OECD sees PPPs as 'long term agreements between the government and a private partner whereby the private partner delivers and funds public services using a capital asset, sharing the associated risks' (2016). In practice, a controversial image of PPPs has been noted due to 'complicated... and...smoky procedural process' (Calabrò and Della Spina apud Ventura, Cassalia and Della Spina, 2016, p. 260) which are thought to be in place of a hidden privatization of public assets (Politika, 2008; Bašić, 2016, p. 28). Despite possibly existing cases of corruption in that matter, this article starts from the premise that public and private parties in PPP projects share the risks both in investment as well as in management. So, rather than insisting on one all-embracing definition, the usual main characteristics of a PPP are offered:

- collaborative effort of two or more public and private autonomous organizations;

- project concerns a public service or good for public consumption;

- durable character of the project;

- development of mutual products and/or services;

- risk, costs, and benefits shared by both parties;

- regulatory responsibility of the public sector;

- payments to the private sector for the delivered services; and

- mutual added value.

'PPPs may deliver public services both with regards to infrastructure assets (such as bridges, roads) and social assets (such as hospitals, utilities, prisons)' (OECD, 2016). Lately, this model has gained a special attention in the field of cultural heritage due to a number of built heritage sites globally that needed interventions. In the next chapter, we specifically focus on public-private partnership in the cultural sector.

3 E.g., PPP Knowledge Lab brings information on the PPP environment for as much as 141 countries worldwide together with a practical guide on PPP investments as well as analyses, challenges and lessons for PPP sectors. 


\section{Public-private partnership in the field of culture}

In many cases the government has been seen as the primary guardian of the nation's heritage, but with the growing pressure to fulfill other public demands and insufficient resources (money and management skills), most governments faced significant challenges in their efforts to conserve and manage their cultural heritage assets (Macdonald, 2011; Macdonald and Cheong, 2014). However, the situation changed and public-private partnerships (PPPs) began to be used for heritage conservation in the late 1960s within the context of urban regeneration schemes (MacDonald, 2011, p. 893). The use of PPPs has slowly expanded to the conservation and management of a range of heritage places, including archeological sites, buildings, landscapes, urban areas, collections, and natural areas of heritage significance (MacDonald and Cheong, 2014 , p. 2) where the third sector (local residents, consumers, and nonprofit organizations), multi-actor engagement and partnerships became highly important for the success of long term projects. The involvement of citizens as individuals (citizen engagement) is very important in the definition of priorities for and directions of PPPs in cultural heritage projects because this kind of projects could have an impact on the daily life of people in the cities (Digital Meets Culture, 2016).

Some countries, such as Netherlands, the United Kingdom, Australia and United States have proven successful in implementing such projects (MacDonald and Cheong, 2014, p. 72). Financing cultural heritage through PPP entails different delivery models: the traditional model, where the public sector is fully responsible for availability and financing of the asset to those which so far have not been common in the field of culture, where the private sector is more involved. The next chapter deals with above mentioned issues in four Central European countries (Croatia, Poland, Slovakia and Slovenia) by focusing on their PPP policy, legal and funding mechanisms and experiences of PPP in culture.

\section{Public-private partnership in Croatia, Poland, Slovakia and Slovenia}

\subsection{PPP policy and legal framework}

PPP exists in all the analyzed countries and while there is experience in PPP in all of them, the policy and legal framework covering PPP vary from country to country. In Croatia, the legal framework dates back to 2008 when the law on PPP was passed for the first time (Public-Private Partnership Act, OG 129/08). The key policy document governing the development of PPP in Croatia is 'The Strategic Framework for the Development of PPP' (2009). The national PPP Act, passed in 2008, stipulates clear rules for all participants in different variations of PPP, and provides a legal framework for the enduring security of the project, both for the private sector and the public bodies (Interreg: Central Europe, RESTAURA, Croatia, 2016, pp. 5-6). In Poland, the formal legal and material framework for the cooperative projects between the private sector and public bodies is regulated by the Act on Public-Private Partnership from 2008. The scope broadly covered under the term PPP is also regulated and 
influenced by the 'Act on Concessions for construction works or services' from 2009 and the Public Procurement Law from 2004. The aforementioned acts regulate the basic principles of public-private cooperation (Interreg: Central Europe, RESTAURA, Poland, 2016, pp. 3-4). 'The Act number 25/2006 on Government Procurement constitutes the rules of public procurement of the contractual work in Slovakia defining conditions on the public procurement of the PPP projects' (Nováćková and Saxunová, 2015, pp. 6-7). Slovakia also has several other documents which cover and encompass the field of PPP in their scope, such as 'Informačný sprievodca PPP, PPP na Slovensku, Aplikace principu PPP při realizaci politiky HSS' and a few more. Slovenia introduced its law governing PPP in 2006. This law on PPP from 2006 is complemented in its scope of legal framework by the Public Procurement Act and Local Government Act. The PPP Act sets the legal regulation regarding the principles of private investment in public projects and public co-financing of private projects determined to be in the public interest. The initiation of a PPP project can, under Slovenian legislation, be undertaken by both the private or public sector actors (Interreg: Central Europe, RESTAURA, Slovenia, 2016, p. 5).

\subsection{Public institutions and PPP support units}

In Croatia, the central national agency for PPP was formed in 2009 in accordance with the Act on PPP. It acted as the knowledge center and regulatory body responsible for evaluation, approval and monitoring of the PPP projects until 2015, when a decision was made on the merger of the Agency for PPP with the Agency for Investments and Competitiveness (AIC). The Sector for PPP within the AIC took over the functions of the Agency for PPP. It oversees the preparation and implementation of PPP projects together with the Ministry of Finance, where the AIC (Sector for PPP) handles the operational workload and the approval for the PPP project proposals, and the Ministry of Finance grants prior consent for the project proposals. The Agency cannot approve PPP project proposals without prior consent received from the Ministry of Finance. Within the framework of the public procurement system, the State Commission for Supervision of Public Procurement is entrusted with the handling of the appeals in the public procurement procedures, the granting of the concessions, and the selection of the private partners in PPP as a body of first instance, and the Administrative Court as the body of second instance. In Poland the key public institution for the framework of PPP is the Ministry of Development, which disseminates and promotes the PPP format, while overseeing and implementing the possibilities and prospects of financial involvement of the private sector in relevant projects. Also, the Agency for Enterprise Development, in cooperation with the private PPP Institute provides significant support for public entities seeking a PPP solution for their project requirements. In Slovakia, the institutions that support the PPP framework are the Slovak Public-Private Partnership Association established in 2007, the Ministry of Finance in a regulative, supportive, supervisory, methodological and coordinative capacity. In Slovenia, the Public Property Management of the Ministry of 
Finance is the main institutional aid to the organization and implementation of PPP projects. There is also the Council of the Government for PPP, which is chaired by the Minister of Finance as well as the Institute for PPP established in 2008 as a private institute with the belief that legal and economic scientific research in the field of PPP should be encouraged, and that the results of the research should be systematically transferred into practice (Interreg: Central Europe, RESTAURA, Slovenia, 2016, p. 5).

\subsection{Incentives and funding mechanisms available for PPP}

There are several funding mechanisms available for a PPP in the Republic of Croatia. First, there is the possibility of a PPP through the concession contract where the private sector bears demand risk. In this model, private partner is usually granted the right to charge the end users for some public service or to use some public goods to create profit. The second option is based on the availability of asset. In this model, the private partner bears the availability risk while the demand risk is retained by the state. The majority of revenues in this model comes from the budget, and it depends on the availability of the assets. Commercial banks can be included in the financing of PPP, and the Croatian Bank for Reconstruction and Development (HBOR) also has a significant role in providing funding for PPP in Croatia. Within the context of European investment policy, there is the possibility of combining PPP models (as a procurement method) and EU funds (as a sources of funding), where the most commonly used financial instruments are JESSICA (Joint European Support for Sustainable Investment in City Areas), LGTT (Loan Guarantee Instrument for Trans-European Transport Network), and the MARGUERITE FUND (Interreg: Central Europe, RESTAURA, Croatia, 2016, pp. 8-9). For Poland, the main instruments in support of PPP implementation have been of legislative nature. The Act on PPP introduced tax incentives on income tax from legal persons and real estate management facilities for local government and the treasury to facilitate PPP solutions. Also, the Ministry of Development has included in its guidelines the eligibility for expenses incurred in relation to the implementation of PPP projects to be reimbursed through grants financed from the European Regional Development Fund, the European Social Fund and the Cohesion Fund for 2014-2020 (Interreg: Central Europe, RESTAURA, Poland, 2016, pp. 8-9). Considering Slovakia, the funding mechanisms available for PPP projects have been the European Investment Bank (EIB) for transactions benefitting from the support of the EU budget guarantee under the European Fund for Strategic Investments (EFSI), the Investment Plan for Europe (IPE) and its financing components, and for PPP projects of smaller value and scope, there has been direct support from the Ministry of Finance of the Slovak Republic (2017). Slovenia currently does not have any legislative incentives or funding mechanisms available for the further development and support of PPP projects (Interreg: Central Europe, RESTAURA, Slovenia, 2016, p. 6). 


\subsection{Experiences of Public-Private Partnership considering cultural heritage}

Croatia has had a relatively large number of cases of PPP, but officially only one case is in the field of cultural heritage, and that concerns the revitalization of the County Palace in Varaždin. It is the only PPP project in the field of cultural heritage that has been realized so far. There are two additional projects in the field of culture which are being developed with the intention of using the PPP framework: revitalization of the Croatian History Museum and the Croatian State Archives. Although Croatia has many cultural heritage sites in need of revitalization, the Registry of Cultural Goods is still incomplete, and since it is the prerequisite for investments in terms of cultural heritage based PPP projects, there are problems still to be solved in order to create a fully functional PPP system for cultural heritage (Interreg: Central Europe, RESTAURA, Croatia, 2016, pp. 20-21).

In Poland, the main document for the protection of cultural heritage is the National Revitalization Plan of 2014. The revitalization of cultural heritage has been rising in importance in Poland in the last 20 years, and the National Revitalization Plan includes a lot of valuable experience gained in previous projects. Also, the Ministry of Development is working on developing standardized documents and valuable caches of good practices and solutions for use in future projects. Since there are many cultural heritage sites and areas in need of revitalization, the National Municipal Policy is planned to include legislative and organizational solutions to complement the tools and instruments developed through previous experience (Interreg: Central Europe, RESTAURA, Poland, 2016, pp. 14-17).

In Slovakia, despite of recent increase in focus by the Slovak government on the general framework of PPP projects and positive steps towards possible changes in the legal framework, the absence of the comprehensive legislative policy for PPP projects application represents, to a certain extent, an obstacle for effective feasibility of these projects. Currently, PPP is mostly regulated by the Act no. 25/2006 Coll. on Public Procurement and the Act no. 523/2004 Coll. on the Public Administration's Budgetary Rules, which leads to the fact that most PPP projects are public works concessions, and that the biggest projects have not been in cultural heritage preservation, but big infrastructure works such as the R1 Highway (Interreg: Central Europe, RESTAURA, Slovakia, 2017, pp. 8-12). On the other hand, the Government of the Slovak Republic outlined the main directions and strategy for the preservation of cultural heritage in its document 'Conception of the protection on monuments and historic sites in Slovakia' in December 2011. Emphasis was placed on the necessity to restore endangered monuments, and on the importance that revitalized heritage has to offer for capacity building, job development, economic growth and social inclusion. The main public institution is the Monument Office of the Slovak Republic and it is, along with its regional monument boards, responsible for management of cultural heritage sites on the regional level. As for the financial sources, they are possible from the Monuments Fund (which alone does not have the resources to perform the restoration and maintenance of cultural heritage sites), local municipalities which, starved for resources, 
cannot place heritage conservation before more immediate budgetary needs, and the Ministry of Culture of the Slovak Republic which provides financial sources for heritage conservation and restoration through its many programs, such as the dotation system 'Renew your house' (Interreg: Central Europe, RESTAURA, Slovakia, 2017, pp. 17-20).

Slovenian cultural heritage revitalization is based on the Cultural Heritage Protection Act, and the main institution in charge of allocating subsidies from the state's budget and European structural fund is the Heritage Information and Documentation Centre of the Directorate for Cultural Heritage at the Ministry of Culture. It maintains the cultural heritage register and is in charge of the supervision of national projects, administration of conservation interventions and archeological research. One of the main obstacles to successful PPP projects in the field of cultural heritage is that a large number of sites are castles and palaces which require revitalization along with their extensive architectural complexes and grounds, necessitating very large investments. Those that have been revitalized mainly serve as tourist attractions and museums. Also, the scope of the demands and the various methods implemented by EU-funded projects have increased the participation and interest of the general public in such projects, giving them a wider support and importance in the social life of their surrounding areas (Interreg: Central Europe, RESTAURA, Slovenia, 2016, pp. 10-16).

Table 1 presents comparative data on PPP situation in Croatia, Poland, Slovakia and Slovenia.

\section{Results of the research on the PPP in culture in Croatia, Poland, Slovakia and Slovenia ${ }^{4}$}

\subsection{Methodology}

The main aim of the research conducted both with public and private sector representatives in four countries (Croatia, Poland, Slovakia and Slovenia) within the RESTAURA project was to gain insights about their knowledge, experiences, needs, expectations and practices in PPP scheme and revitalization as well as their attitudes, views, and plans for future activities. The main hypothesis of this research was that the relevant stakeholders have knowledge on PPP as well as on cultural heritage but there is no clear perception of the possibilities of heritage revitalization through the PPP models. Research questions focused on experiences in PPP, needs for cultural heritage revitalization, possible sources of financing cultural heritage revitalization, cooperation between public and private sector, and opportunities for enhanced coop-

4 The research was prepared within the RESTAURA project by the Foundaton for Landscape Protection (FOK) from Poland and conducted by all RESTAURA project partners. After conducting questionnaires, each project partner delivered to FOK its summary report from questionnaires. The research results from all four countries were summarized by FOK (Interreg: Central Europe, RESTAURA, Summary Report: FOK, Version 1, 2017). 
Table 1: PPP framework in Croatia, Poland, Slovakia and Slovenia

\begin{tabular}{|c|c|c|c|c|}
\hline COMPARATIVE ANALYSIS & CROATIA & POLAND & SLOVAKIA & SLOVENIA \\
\hline \multicolumn{5}{|l|}{ Legal PPP framework } \\
\hline PPP Act & Yes & Yes & $\mathrm{No}^{1}$ & Yes \\
\hline Institutional PPP model & + & + & - & + \\
\hline Contractual PPP model & + & + & + & + \\
\hline Service based model & + & + & + & + \\
\hline Availability based model & + & + & + & + \\
\hline Government PPP policy strategy & + & - & - & - \\
\hline PPP project pipeline approved by government & - & - & - & - \\
\hline \multicolumn{5}{|l|}{ Institutional framework } \\
\hline Independent PPP regulatory body & Yes $^{2}$ & $\mathrm{No}^{3}$ & $\mathrm{No}^{4}$ & Yes $^{5}$ \\
\hline Public body responsible for fiscal risk issues & $\begin{array}{l}\text { Ministry } \\
\text { of Finance }\end{array}$ & $\begin{array}{l}\text { Ministry } \\
\text { of Finance }\end{array}$ & $\begin{array}{l}\text { Ministry } \\
\text { of Finance }\end{array}$ & $\begin{array}{l}\text { Ministry } \\
\text { of Finance }\end{array}$ \\
\hline PPP promotor & AlC & $\begin{array}{c}\text { PPP } \\
\text { Institute }\end{array}$ & $\begin{array}{c}\text { PPP } \\
\text { Association }\end{array}$ & $\begin{array}{c}\text { PPP } \\
\text { Institute }\end{array}$ \\
\hline PPP project proposal (application) & $\begin{array}{c}\text { Public } \\
\text { body only }\end{array}$ & $\begin{array}{c}\text { Public } \\
\text { body only }\end{array}$ & $\begin{array}{c}\text { Public } \\
\text { body only }\end{array}$ & $\begin{array}{c}\text { Public } \\
\text { body only }\end{array}$ \\
\hline \multicolumn{5}{|l|}{ Available funding mechanisms } \\
\hline State budget & + & + & + & + \\
\hline EU funds & + & + & + & - \\
\hline National investment bank PPP program & + & - & + & - \\
\hline Project bonds & - & + & + & - \\
\hline Commercial banks & + & + & + & + \\
\hline \multicolumn{5}{|l|}{ PPP projects in Culture Heritage sector } \\
\hline Projects in preparation & 2 & 0 & 0 & 0 \\
\hline Projects in implementation & 1 & 0 & 0 & 0 \\
\hline $\begin{array}{l}1 \text { PPP in Slovakia is mostly regulated by the Act n } \\
523 / 2004 \text { Coll. on the Public Administration's Bu } \\
2 \text { Agency for Investments and Competitiveness, C } \\
3 \text { Ministry of Development, Poland } \\
4 \text { Ministry of Finance, Slovakia } \\
5 \text { PPP Council, Slovenia }\end{array}$ & $\begin{array}{l}5 / 2006 \text { Coll. } \\
\text { tary Rules. } \\
\text { tia }\end{array}$ & Public Proc & ement, and th & Act no. \\
\hline
\end{tabular}

eration based on PPP. Two different surveys were conducted with private and public institutions from October to November 2016. Both questionnaires consisted of mainly multiple choice questions and some open-ended ones.

In total, 114 answers were received out of which 79 were from public institutions and 35 from private entities. The majority of answers were from Poland (45), following Slovenia (31), Croatia (24) and Slovakia (13).

Regarding public institutions structure, municipalities accounted for half of the entities under research, following other institutions related to the cultural heritage such as museums, natural parks, ministries, municipal offices, educational, tourism and city agencies, and even health service. Out of 79 received answers from public institutions, 35 were from Poland, 22 from Slovenia, 13 from Croatia, and 9 from Slovakia. Considering the fact that the number of PPP projects in the field of culture is 
pretty low, it was hard to select private institutions which are related to the PPP in revitalization. Thus, private entities in this research included private companies in general. In total, 35 answers from private entities were collected: 11 from Poland, 11 from Croatia, 9 from Slovenia, and 4 from Slovakia.

\subsection{Results}

The research results had shown that $51 \%$ of private entities expressed interest in implementation of PPP projects, and 54\% were not able to specify it. On the other side, $42 \%$ of the public respondents declared interest in future revitalization projects within the PPP scheme, but open-ended questions revealed that finding a partner can be one of the main obstacles for them.

According to the research results, private companies had more experience in the PPP than public authorities. The majority of public institutions (at least 68\%) did not have any experience related to PPP scheme, meaning they neither participated in the procedure of selecting the private partner, nor had ongoing PPP projects, nor completed one. Only about $10 \%$ of the public institutions had implemented PPP projects. Also, $68 \%$ of public institutions admitted that they had not taken any actions yet regarding institutional preparation for PPP projects, nor research regarding the interest of private companies in implementing revitalization projects under PPP scheme within their institution ( $89 \%$ ). On the other side, $47 \%$ of the private companies reported lack of experience in PPP. In both cases Slovakia was the leader with 100\% of negative answers.

Regarding revitalization issues and cultural heritage, public authorities showed high levels of knowledge and awareness. When it comes to the question related to the revitalization issues and cultural heritage, the majority of public authorities (88\%) showed higher awareness saying that they found revitalization needs within their area of influence important. Respondents were asked to offer an estimation on the number of buildings and sites with revitalization needs which are under the heritage protection law. They gave various answers, from several buildings to several hundreds of buildings. It can be assumed that different answers are the result of the lack of national registries of cultural heritage of any kind and lack of understanding and recognition from the wider audiences (media, public, local governments, etc.) on the importance of cultural heritage buildings.

For public authorities, funding was a major obstacle for the revitalization of historic buildings. $80 \%$ of the respondents from public sector considered that their own funds for revitalization are insufficient because restoration and revitalization of cultural and historical heritage requires large funds and other types of funding. On the other side, for $48 \%$ of respondents, the EU and national funds would be sufficient, but, according to some respondents, they are sufficient to cover only documentation costs and certain revitalization activities, but not all. Regarding major obstacles for revitalization of historic buildings, $46 \%$ of the public respondents did not see any major difficulties arising from the obligation to comply with conservation requirements, while $31 \%$ of the 
respondents saw them as a significant obstacle for revitalization of historic buildings. $35 \%$ of the interviewed private companies said that they did not see any major difficulties arising from the obligation to comply with conservation requirements, while $30 \%$ of them said that they have not cooperated before with the heritage conservation services, and it is difficult for them to estimate the possible obstacles.

For public authorities, major factors that may contribute to increasing their involvement in PPP projects included standardized documentation (e.g., sample agreements, guides regarding the preparation of PPP projects, key documents, etc.) which they found very important, then funding for the preparation of documentation for PPP, improved legal framework and consistent strategy for the country, and access to external expert support. Some of them specified other factors equally important such as: project co-financing by the government in case of non-profit organizations, transparency model, and increasing confidence in public sector.

According to private entities, main obstacles on the side of private companies and public authorities in the implementation of PPP projects were little knowledge on how to implement PPP projects, high cost of preparation of PPP projects, and legal and institutional framework. Actions that would help overcoming these obstacles were external funding for the preparation of documentation, familiarization with handbooks and other PPP documents, individual consultations with PPP experts, trainings and workshops, or successful implementation of PPP projects.

Regarding implementation of projects within the PPP scheme, both public and private institutions had negative perceptions about each other. $60 \%$ of private respondents considered public sector preparation for the implementation of projects within the PPP scheme as insufficient, and 38\% of them said that they had an average level of preparation. $47 \%$ of public institutions considered the private sector's preparation for the PPP cooperation as insufficient, and 50\% of them said that they had an average level of preparation.

The general conclusion from the research is that there is an evident lack of cooperation between private and public sector in all four analyzed countries. The majority of public authorities (89\%) said they have not taken any research regarding the interest of private companies in implementing revitalization projects under PPP scheme with their institution, and private companies said they did not have much experience with public authorities regarding PPP in revitalization of historic buildings because, in some cases, there were revitalization priorities other than historic buildings.

The case of Slovakia showed that neither public sector nor private sector had any experience with PPP projects and revitalization of historic buildings. Thus, some of the possible future steps to increase the number of institutions implementing PPP projects mentioned in this research were: higher promotion of PPP in Slovakia and sharing good practice examples, developing PPP manuals and other documents related to PPP, organizing trainings and workshops, funding for the preparation of documentation, and also increasing knowledge about nationally important sites and buildings with revitalization needs. 
Conclusions arisen from the case of Slovenia showed that the PPP is still not well developed. Research results showed that all institutions, especially public ones should put more focus on educational programs, meetings, consultations and events where the contacts between public institutions and potential private partners could be encouraged. Also, the whole system of PPP should be more transparent and simplified with a focus on examples of successful practices.

Results from the Poland case showed that private institutions had considerable experience and knowledge on the PPP. On the other side, public institutions were interested in implementing projects within the PPP scheme but they were also aware that they lacked knowledge on how to implement these projects.

In Croatia, both private and public institutions were highly interested in implementing PPP projects, but had negative perceptions about each other. For public institutions funding was a major obstacle for revitalization activities, while private partners were mostly uninformed about revitalization issues. Also, private companies did not have experience with public authorities regarding PPP, and public institutions have not taken any research regarding the interest of private companies in implementing PPP projects in revitalization.

In general, the results from the questionnaires showed that there was an evident lack of cooperation between both private and public institutions in all four countries. Although Poland showed considerable experience and knowledge on PPP (especially private companies), all four countries expressed the need for more educational programs in PPP for both private and public institutions. Regarding revitalization of historic buildings, funding was considered as one of the main obstacles for implementation of PPP projects in revitalization. Therefore, standardized documentation, funding for the preparation of documentation for PPP, improved legal framework and consistent strategy for the country, as well as access to external expert support were seen as major factors that may contribute to increasing their involvement in PPP projects. Also, special attention should be given to increasing knowledge and awareness in all four countries on nationally important sites and buildings with revitalization needs and cultural heritage in general.

\section{Conclusions}

Public-private partnership can be seen as a new, alternative way of cultural heritage financing since it provides new, alternative ways and new source of capital for culture coming from the private sector. On the other hand, it provides certainty that the cultural heritage asset will retain its intrinsic values due to the involvement of the public sector. Unjustly, PPP projects have been stigmatized due to the wrong perception of the private sector involvement which was accused of 'privatization' and commercialization of cultural values. Well prepared PPPs should share resources, responsibilities and risks stemming from such a partnership.

So far, the literature on PPP in cultural heritage revitalization as well as practical projects are limited, especially in the Central and East European countries which 
would greately benefit from it since the government financing for public assets is extremely limited. Prerequisites to successful PPPs in cultural heritage conservation are expertize, PPP policy, legal framework, as well as the existence of a marketplace which is willing to invest.

The research presented in this article has shown that in the researched countries, Croatia, Poland, Slovakia and Slovenia, national policies and PPP legal and institutional framework, together with designated institutional support can result in significant savings and create 'value for money' in public sector investments. However, marketplace incentives are still not sufficiently developed as to attract larger volume of private investments and enable long-term positive effects on macroeconomic implications.

Although all the analyzed countries have developed the policy and the legal framework, they are different. All the four countries have designated laws regulating PPP but they differ in terms of institutions in charge of it. In some countries (Croatia), there is a designated public institution, in others responsibility for PPP stays within the ministerial scope (Slovenia) or responsibilities are shared (Slovakia, Slovenia).

When it comes to the funding mechanisms, they also differ ranging from concession contracts, funding based on the availability of assets, combining PPP models and EU funds, project bonds financing, etc. Only Slovenia currently does not have any legislative incentives or funding mechanisms available.

In the field of culture, Croatia stands out, but there is only one case of PPP contract in implementation and two of them are in preparation. The other countries so far have not managed to revitalize cultural heritage assets by way of PPP contracts.

The research of PPP in the four countries has proved that private sector is more experienced in PPP than the public one whereas only about one tenth of public sector institutions implemented PPP projects. Public sector operated relatively slow either in the preparation for PPP projects, or in research regarding the interest of private companies in implementing revitalization projects under PPP scheme. Still, they show high awareness of the revitalization needs.

The greatest problems in using PPP in heritage revitalization seems to be the lack or incompleteness of national registries of cultural heritage as well as the relatively low level of public knowledge on the importance of cultural heritage. When it comes to the public sector alone, the lack of funding is presented as a major culprit for insufficient revitalization of historic buildings. Private sector sees three main issues as obstacles for revitalization of heritage based on PPP: insufficient knowledge on the implementation of PPP projects, high cost of preparation of PPP projects, as well as legal and institutional framework.

When it comes to the implementation of projects within the PPP scheme, negative perceptions of both public and private institutions about each other is evident which results in the lack of cooperation between private and public sector in all four analyzed countries. This also affects the lack of pro-active research by the public sector of the interest of private companies in implementing revitalization projects under PPP 
scheme; on the other hand private sector often has different revitalization priorities than historic buildings.

Solutions to such a situations are sought in educational programs in PPP for both private and public institutions, standardized documentation, funding for the preparation of documentation for PPP, improved legal framework and consistent strategy for the country, as well as access to external expert support. It is believed that fulfilling these prerequisites could contribute to increasing public and private sector involvement in PPP projects.

Also, in order to achieve sustainable projects and bearing in mind that the PPP model is primarily one of the possible procurement options for realizing projects of public interest which includes significant participation of private sector (Coulson, 2008), it is highly recommended during the preparation of public investment projects, as well as the projects in heritage revitalization (regardless of the model chosen): (i) to focus on the whole life costs of the assets (rather than just capital costs), (ii) to use an output specification approach (rather than just input specification approach) for describing public sector needs, (iii) to identify available procurement and financing options (PPPs, EU funds, combining PPPs and EU funds, financial instruments, etc.), (iv) to strengthen market support and to highlight the fact that PPP presents an optimal model where the public authorities retain full control of the investments while the private sector participation is limited and firmly regulated.

\section{References:}

1. Bašić, T., 'Kako se uključiti u novi val JPP-a', 27 January 2017, Lider, pp. 26-30.

2. Coulson, A. 'Value for Money in PFI Proposals: A Commentary on the UK Treasury Guidelines for Public Sector Comparators', 2008, Public Administration, vol. 86, no. 2, pp. 483-498.

3. Digital Meets Culture, 'Public-Private Partnerships for Cultural Heritage: Opportunities, Challenges, Future Steps', Think Papers Collection/07, Riches Resources, 2016, [Online] available at available www.digitalmeetsculture.net/wp-content/uploads/2016/ 04/rch_thinkpapers_07.pdf, accessed on June 9, 2017.

4. European Commission, Directorate-General for Education, Youth, Sport and Culture, 'Towards More Efficient Financial Ecosystems. Innovative Instruments to Facilitate Access to Finance for the Cultural and Creative Sectors (CCS): Good Practice Report', Luxembourg, 2016, [Online] available at https://publications.europa.eu/en/publication-detail/-/publication/f433d9df-deaf-11e5-8fea-01aa75ed71a1/language-en, accessed on March 5, 2017.

5. European Expertise Centre, 'Market Update Review of the European PPP Market in 2016', [Online] available at www.eib.org/epec/resources/publications/epec_market update_2016_en, accessed on June 8, 2017.

6. European Parliament, Directorate General for Internal Policies, Policy Department B, 'Structural and Cohesion Policies, Encouraging Private Investment in the Cultural Sector. Study', Brussels, 2011, [Online] available at www.europarl.europa.eu/RegData/ etudes/etudes/join/2011/460057/IPOL-CULT_ET\%282011\%29460057_EN.pdf, accessed on March 4, 2017. 
7. Interreg: Central Europe, 'RESTAURA: Revitalizing Historic Buildings through Public-Private Partnership Schemes (CE339), Country Report on the Legal Framework on Public-Private Partnership (PPP): CROATIA', Version 1, November 2016, [Online] available at www.interreg-central.eu/Content.Node/RESTAURA/D.T1.2.1-Countryreport-Croatia-V1.pdf, accessed on March 3, 2017.

8. Interreg: Central Europe, 'RESTAURA: Revitalizing Historic Buildings through Public-Private Partnership Schemes (CE339), Country Report on the Legal Framework on Public-Private Partnership (PPP): POLAND', Version 1, November 2016, [Online] available at www.interreg-central.eu/Content.Node/RESTAURA/D.T1.2.1-Country-reportPoland-V1.pdf, accessed on March 3, 2017.

9. Interreg: Central Europe, 'RESTAURA: Revitalizing Historic Buildings through Public-Private Partnership Schemes (CE339), Country Report on the Legal Framework on Public-PrivatePartnership(PPP):SLOVENIA', Version1, November2016, [Online] available at www.interreg-central.eu/Content.Node/RESTAURA/D.T1.2.1-Country-reportSlovenia-V1.pdf, accessed on March 3, 2017.

10. Interreg: Central Europe, 'RESTAURA: Revitalizing Historic Buildings through Public-Private Partnership Schemes (CE339), Country Report on the Legal Framework on Public-Private Partnership (PPP):SLOVAKIA, Version 1, November 2016, [Online] available at www.interreg-central.eu/Content.Node/RESTAURA/RESTAURA-Country-rep orts.html, accessed on March 3, 2017.

11. Interreg: Central Europe, 'RESTAURA: Revitalizing Historic Buildings through Public-Private Partnership Schemes (CE339), Outcome from Questionnaire on the Public-Private Partnership: Summary Report', FOK, Version 1, 2017.

12. Macdonald, S. 'Leveraging Heritage: Public-Private, and Third Sector, Partnerships for the Conservation of the Historic Urban Environment', ICOMOS $17^{\text {th }}$ General Assembly, Paris, France, 2011, [Online] available at http://openarchive.icomos.org/1303/1/ IV-3-Article2_Macdonald.pdf, accessed on June 4, 2017.

13. Macdonald, S. and Cheong, C., 'The Role of Public-Private Partnerships and the Third Sector in Conserving Heritage Buildings, Sites, and Historic Urban Areas', Los Angeles: The Getty Conservation Institute, 2014, [Online] available at www.getty.edu/con servation/publications_resources/pdf_publications/pdf/public_private.pdf, accessed on February 5, 2017.

14. Ministry of Finance of the Slovak Republic, 2017, [Online] available at www.finance. gov.sk/en/Default.aspx?CatID=418, accessed on March 3, 2017.

15. Nováćková, D. and Saxunová, D., 'The Public-Private Partnership Projects Legislation and PPP Project Experience in Slovakia', Management International Conference, Portorož, Slovenia, May 28-30, 2015, [Online] available at www.fm-kp.si/zalozba/ ISBN/978-961-266-181-6/155.pdf, accessed on February 9, 2017.

16. Oppio, A. and Torrieri, F., 'Supporting Public-Private Partnership for Economic and Financial Feasibility of Urban Development', 2016, Procedia - Social and Behavioral Sciences, vol. 223, pp. 62-68.

17. Politika, 'Javno-privatna prijevara', 2008, [Online] available at http://pollitika.com/javno-privatna-prijevara, accessed on February 9, 2017.

18. Organisation for Economic Co-operation and Development (OECD), 'OECD Principles for Public Governance of Public-Private Partnerships', 2016, [Online] available 
at www.oecd.org/gov/budgeting/oecd-principles-for-public-governance-of-public-pri vate-partnerships.htm, accessed on February 9, 2017.

19. PPP Knowledge Lab, 'What is the PPP Reference Guide?', 2015, [Online] available at https://pppknowledgelab.org/ppp-cycle/what-ppp, accessed on February 9, 2017.

20. Ventura, C., Cassalia, G. and Della Spina, L., 'New Models of Public-Private Partnership in Cultural Heritage Sector: Sponsorships between Models and Traps', 2016, Procedia - Social and Behavioral Sciences, vol. 223, pp. 257-264. 